Dept. of Chemistry, Nutritional Deficiency and Toxin.

Animal Health Research Institute,

Zagazig Laboratory.

\title{
HYPOMAGNESAEMIA IN BEEF CALVES AND ITS RELATION WITH PARATHYROID HORMONE LEVEL
}

(With 5 Tables)

\author{
By \\ F.H. EL-SANGARY;A.M. EL-BARAWY;AMINA FARIS \\ and SAHAR S. ABD EL-HAMIED* \\ * Dept. of Clinical Pathology, Animal Health Research Institute, \\ Zagazig Laboratory \\ (Received at 10/9/2011)
}

نقص عنصر الماغنسيوم فى عجول الأبقار وعلاقته بمستوى هرمونات الغدة الجار درقية

فؤاد حامد السنجرى ، عبد العظيم محد البراوى ، أمبين السبي فارس ، سحر سمير عبل الحمبا معل البراي

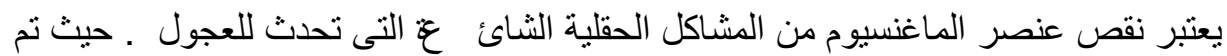

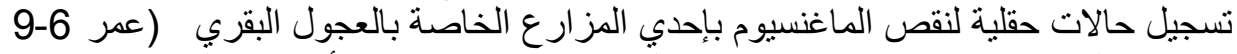

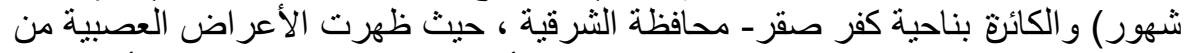

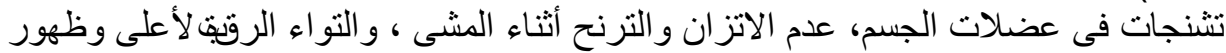

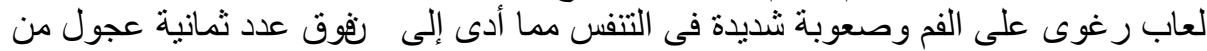

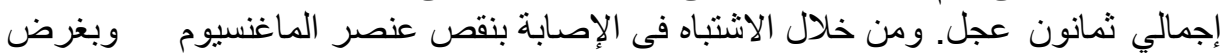

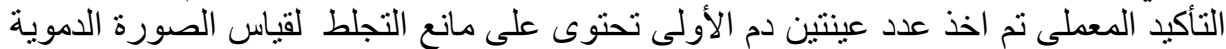

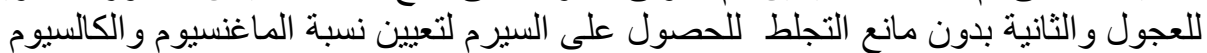

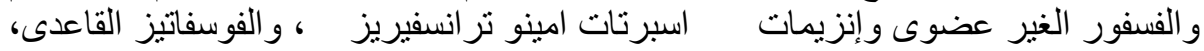

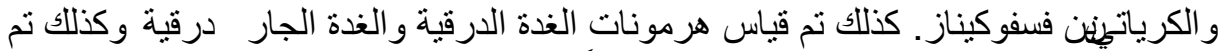

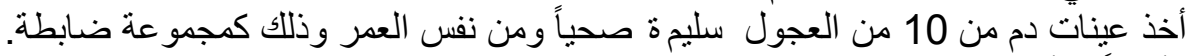

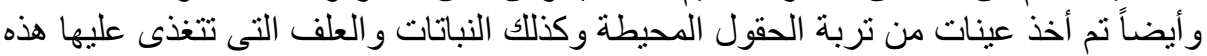

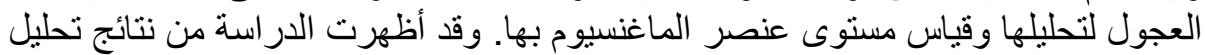

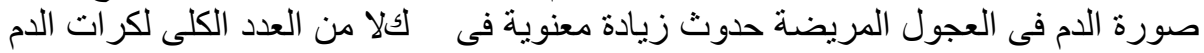

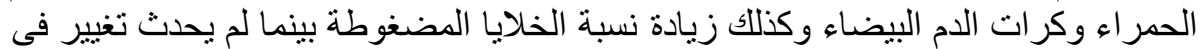

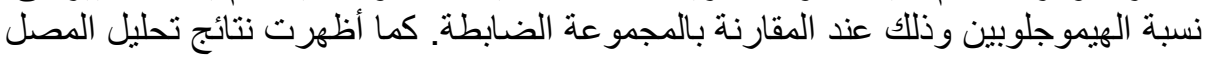




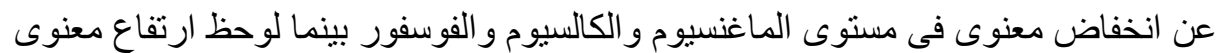

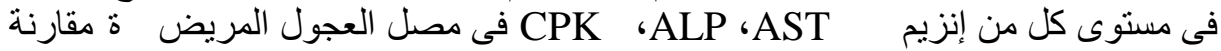

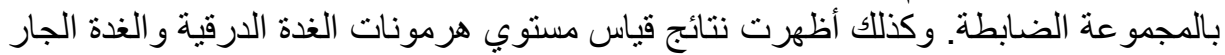

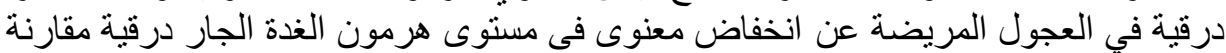

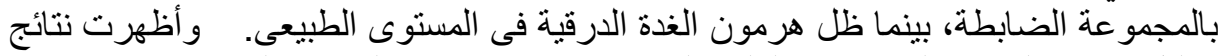

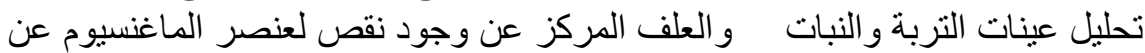

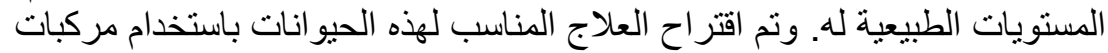

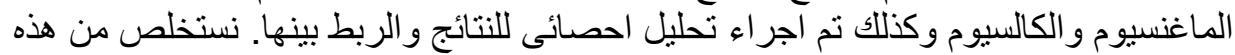

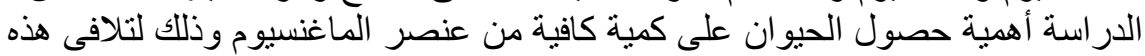

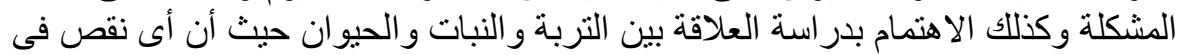
العناصر المعدنية فى أحدهم ينعكس بالتالى على الآخر.

\section{SUMMARY}

Hypomagnesaemia was reported as a common clinical problem in beef calves in Egypt. This study was conducted in a private farm for cow calves $(\mathrm{n}=80)$, 6-9 month of age, in Kafr Sakr City, Sharkia Governorate. The clinical signs appear on some calves including nervous signs, muscular tremors, opisthotonus, polyuria, frequent defecation, frothing at the mouth and convulsions. Only eight calves were died within ten days. The signs suspect hypomagnesemia which confirmed through a biochemical analysis of serum magnesium, calcium and phosphorus. The activities of serum aspartate aminotransferase, alkaline phosphatase and creatine phosphokinase and serum thyroid and parathyroid hormones were estimated. Haematological picture of hypomagnesaemic animals were also determined. Another blood samples were taken from clinically healthy calves $(n=10)$ at same age and area and used as control group. Soil, plant, and concentrate samples were taken for chemical analysis for detection the relation between soil, plant and animal. The haematological observations of the study revealed a significant elevation of total erythrocytic count, total leukocytic count and packed cell volume in hypomagnesaemic calves, while hemoglobin was unchanged. Serum parameters including Mg., Ca. and Phos. showed a significant decrease between diseased and control group. The serum enzymatic activities indicated an increase in AST, ALP and CPK comparing with the control group. Also, the biochemical analysis revealed a significant decrease in serum parathyroid hormone level in hypomagnesaemic calves, while, the thyroid hormones still within the normal range. The chemical analysis of soil, plant and concentrate samples revealed a decrease of $\mathrm{Mg}$. level in them than the normal range. 
We can concluded from this study a strong relationship between the soil, plant and animal, this relationship needs more detailed studies.

Key words: Hypomagnesaemia, beef calves, parathyroid hormone.

\section{INTRODUCTION}

Hypomagnesaemia is an important metabolic disorder affecting ruminants (Radostits et al., 2000), resulting from a primary dietary deficiency of magnesium which is an essential component of more than 300 enzymes that regulate many body functions, such as ATPases, kinases and phosphatases; in RAN, DAN and protien synthesis; and as a regulator of membranes and modulator of synaptic transmission in skeletal muscle (Urdaz et al., 2003). The disorder is associated with low levels of magnesium in the blood and cerebrospinal fluid and is characterized by nervous signs including initial excitement, bellowing, muscle spasms, tetany, convulsions, and sudden death. The development of hypomagnesaemia is dependent on a balance of magnesium intake versus loss, which is determined by both host and environmental influences (Smith, 1996). Calves are very sensitive to changes in the input-out put balance of magnesium in their bodies because they have no readily available magnesium reserve. Hypomagnesemia has a short clinical course and high fatality rate, especially when it is pronounced (Martens and Schweigel, 2000).

In farm stock, element deficiencies and imbalances are mainly related to the soil, where the normal soil produce plants with adequate level of minerals which meet the normal needs of animals. So, the soilplant-animal interrelations are quite complex, where, the deficiency conditions in the animal are a reflection of a deficiency of a particular mineral in the soil and in the plant that grows in this soil (Underwood and Suttle, 1999).

The aim of this work was to study the hypomagnesaemia in beef calves and its relation with different circumstances which can lead to a reduction in magnesium concentration in the blood.

\section{MATERIALS and METHODS}

\section{(A) Animals:}


Hypomagnesemia occurred in a beef calves herd (6 - 9 months of age) in May 2010 in private farm in Kafr Sakr City, Sharkia Governorate. The herd $(\mathrm{No}=80)$ had been fed over winter on poor quality hay and then turned out onto green fooder (Darawa) in spring season. The animals had been supplemented with concentrate at same time. Only 8 calves were died suddenly within ten days, these calves showed nervous signs as muscle tremors, mild tetany of hind legs and staggering gait, also, show frequent defaecation and urination, clamping of jaws and frothing at mouth. No carcass was available for potsmortem examination. The signs suspect hypomagnesemia which confirmed later through biochemical analysis. Other ten clinically healthy calves of the same age and same area, were used as a control group.

\section{(B) Samples and adopted methods:}

(1) Boold samples: Two blood samples were collected randomly from only ten calves through jugular vein puncture. The first one was with EDTA as anticoagulant for haematological studies according to Jain (1986). The second blood sample was without anticoagulant to obtain clear non haemolysed sera for measuring the activities of serum aspartate aminotransferase, alkaline phosphatase and creatine phosphokinase enzymes, spectrophotometrically using special kits accarding to Thefeld et al. (1974); Young et al. (1975) and Rec. GSCC, (1977) respectively. Also, serum magnesium, calcium and phosphorus levels were measured, spectrophotometrically using special kits according to Bohuon (1962); Gindler (1972) and Goldenberg (1966) respectively. Serum thyroid and parathyroid hormones were determined by Radio Immunoassay (RIA) according to Mayer et al. (1979).

(2) ${ }^{(*)}$ Plant sample: (Trifolium alexandrinum) was taken to chemical analysis for determination of magnesium, calcium, and phosphorus levels.

(3) Soil samples: were collected at depth of 25 and $50 \mathrm{~cm}$, mixed and subjected to chemical analysis for determination the level of same elements above.

(4) Concentrate sample: was taken to chemical analysis for determination of magnesium, calcium and phosphorus levels. The analysis were done as described by AOAC (1980) using atomic absorption spectrophotometer.

(*) The chemical analysis of soil, plant and concentrate samples were done in the Central Lab. of Faculty of Agriculture and Faculty of Vet. Medicine, Zagazig University. 


\section{(C) Treatment: The recommended treatment were:}

(1) Magnesium sulphate $20 \%$ slow I/V: In dose rate of $100 \mathrm{ml}$ for three successive days for each calf.

(2) Calcium borogluconate $20 \% \mathrm{I} / \mathrm{V}$.: In dose rate of $250-300 \mathrm{ml}$ for three days.

(3) Vit. $D_{3}$ : I/M: in dose rate of $20.000 \mathrm{IU} / \mathrm{kg} \mathrm{B.W}$ single dose.

(D) Statistical analysis: of data was performed according to Snedecor and Cochran (1994).

\section{RESULTS}

Table 1: Some haematological parameters (Mean \pm SE) in hypomagnesaemic calves compared with the control calves.

\begin{tabular}{|l|c|c|}
\hline \multicolumn{1}{|c|}{ Parameters } & Healthy control calves & Hypomagnesaemic calves \\
\hline R.B.Cs $\left(10^{6} / \mu \mathrm{L}\right)$ & $6.37 \pm 0.16$ & $7.69 \pm 0.19^{* * *}$ \\
\hline W.B.Cs $\left(10^{3} / \mu \mathrm{L}\right)$ & $8.71 \pm 0.7$ & $14.6 \pm 0.58^{* * *}$ \\
\hline $\mathrm{Hb}(\mathrm{g} / \mathrm{dl})$ & $9.13 \pm 0.64$ & $10.3 \pm 0.32$ \\
\hline P.C.V $(\%)$ & $28.9 \pm 0.81$ & $34.0 \pm 0.63^{* * *}$ \\
\hline
\end{tabular}

*** Significant at 0.001

Table 2: Biochemical analysis of serum magnesium, calcium and phosphorus (Mean \pm S.E) in hypomagnesaemic calves compared with the control calves.

\begin{tabular}{|l|c|c|}
\hline \multicolumn{1}{|c|}{ Parameters } & Healthy control calves & Hypomagnesaemic calves \\
\hline Magnesium (mg/dl) & $2.8 \pm 0.51$ & $1.4 \pm 0.24^{*}$ \\
\hline Calcium $(\mathrm{mg} / \mathrm{dl})$ & $10.54 \pm 0.27$ & $8.2 \pm 0.33^{* * *}$ \\
\hline Phosphorus $(\mathrm{mg} / \mathrm{dl})$ & $6.41 \pm 0.19$ & $4.53 \pm 0.18^{* * *}$ \\
\hline
\end{tabular}

* Significant at 0.05 *** Significant at 0.001

Table 3: Seram enzymatic activities (Mean + S.E) in hypo-magnesaemic calves compared with the control calves. 


\begin{tabular}{|l|c|c|}
\hline AST (units/L) & $67.61 \pm 5.6$ & $141.3 \pm 9.21^{* * *}$ \\
\hline Alkaline Ph. (U/L) & $114.19 \pm 6.87$ & $181.7 \pm 11.07^{* * *}$ \\
\hline CPK (U/L) & $16.11 \pm 2.13$ & $42.9 \pm 1.61^{* * *}$ \\
\hline
\end{tabular}

*** Significant at 0.001

Table 4: Serum thyroid and parathyroid hormones concentrations (Mean \pm S.E) in hypomagnesaemic calves compared with the control calves.

\begin{tabular}{|l|c|c|}
\hline \multicolumn{1}{|c|}{ Parameters } & Healthy control calves & Hypomagnesaemic calves \\
\hline $\mathrm{T}_{3}(\mathrm{ng} / \mathrm{ml})$ & $49.29 \pm 2.8$ & $51.37 \pm 2.1$ \\
\hline $\mathrm{T}_{4}(\mu \mathrm{g} / \mathrm{ml})$ & $1.41 \pm 0.33$ & $1.93 \pm 0.18$ \\
\hline PTH $(\mathrm{pg} / \mathrm{ml})$ & $9.71 \pm 1.42$ & $5.93 \pm 0.17^{*}$ \\
\hline
\end{tabular}

* Significant at 0.05

Table 5: Chemical analysis of soil, plant and concentrate (mean value)

\begin{tabular}{|c|c|c|c|c|c|}
\hline \multirow{2}{*}{ Parameter } & \multicolumn{2}{|c|}{ Soil } & \multicolumn{2}{c|}{ Plant } & Concentrate \\
\cline { 2 - 6 } & $\begin{array}{c}\text { Delta } \\
\text { area }\end{array}$ & $\begin{array}{c}\text { Examined } \\
\text { soil }\end{array}$ & $\begin{array}{c}\text { Trifolium } \\
\text { alexandrinum }\end{array}$ & $\begin{array}{c}\text { Examined } \\
\text { plant }\end{array}$ & \\
\hline Calcium ppm & 161.67 & 39.00 & 1934.00 & 712.00 & - \\
\hline Phosphorus ppm & 294.28 & 55.00 & 1811.00 & 625.00 & - \\
\hline Magnesium ppm & 212.33 & 60.00 & 2100.00 & 341.00 & 159.00 \\
\hline
\end{tabular}

\section{DISCUSSION}

Hypomagnesemia is a disorder affecting animals not receiving adequate available magnesium. The low availability of magnesium in 
forage may be form either low magnesium concentration or to factors in the forage that reduce availability of magnesium to the animal (Grunes 2004).

The clinical signs observed on the hypomagnesaemic calves in this study were hyperirritability of the nervous system and the development of tetany which terminate in spasticity, opisthotonus and violent convulsions, during which, the respiratory movements may temporarily be abolished. The recorded clinical signs were coincided with that previously mentioned by Radostits et al. (2000); Smith, (1996). This may be attributed to the central effect of magnesium with the nervous system by activating choline esterase which breaks down acetyl choline, therefore central nervous system was in a hyper- irritable state during magnesium deficiency.

Most affected calves were at 4-9 months of age, this may be explained as the absorption ability of magnesium decreased to about $20 \%$ at five months of age (Smith, 1996).

Table (1) show the haematological finding in hypomagnesemic calves, where there is a significant increase in red blood cells, leukocytic count and packed cell volume, while, the haemoglobin level showed a non significant variation in comparison with control group. These results are similar to those obtaine and by Kirtidua and Nauriyal, (1988) and Sarode et al. (1993).

Serum biochemical analysis of magnesium, calcium and phosphorus showed significant decrease in their levels in hypomagnesaemic calves as compared with the control ones (Table 2). This reduction in magnesium level which was accompained with reduction in calcium level is agreeable with that recorded by Smith (1996) that hypomagnesemia is often associated with hypocalcemia and magnesium deficiency may influence calcium homostasis. Where, magnesium increases calcium release from the bone by displacing it from the hydration shell and by stimulating processes which involve the simultaneous catabolism of the matrix and mineral phase, thus, magnesium deficiency would lead to a decrease in calcium release from the bone and hence reduce its concentration.

Serum magnesium level is a major determinant of magnesium status of an animal, and it is a good basic indicator of both dietary adequacy and nutritional status (Herdt et al., 2000). The neurologial manifestations are reflective of cerebrospinal fluid magnesium concertation which are related to serum in a linear pattern at markedly low level of magnesium in the blood (Martens and Schweigel 2000). 
Also, unlike the metabolism of many other essential minerals, there is no specific hormonal system to regulate magnesium homeostasis (Urdaz et al., 2003). The kidney is able to excrete excess magnesium, but it is unable to conserve enough magnesium systemically in situations of deficiency. So, the daily dietary magnesium intake is very important for animal, where, there is only a small reserve of magnesium in the body fluids, and bone metabolism is often insufficient to meet increased magnesium requirements when demand is increased (Odette, 2005). Furthermore, the feeding of the calves in this study on hay and concentrate acts as a stressor where, the availability and absorption of ingested magnesium decreased when rumen ammonia concentration increased due to high protein levels (Dryden 2008). This stress may lead to clinical hypomagnesemia, since sympathetic nervous system activation causes an epinephrine release resulting in a decreased plasma magnesium concentration (Martens and Schweigel 2000).

Table (3) show the activities of serum aspartate aminotransferase, Alkaline phosphatase and creatine phosphokinase enzymes in both control and hypomagnesemic calves groups. It reveals an significant increase in the mean values of these enzymes than normal level. Similar findings were recorded by Radostitis et al. (2000). The elevation in the activity of AST can be associated with the pathology involving hepatic cells, skeletal or cardiac muscles, thereby allowing the leakage in large quantities (Jayanthi et al., 1997). Liver dystrophy in hypomagnesemia was reported by Vrzgula (1990). As a result of muscular damage and necrosis associated with deficiency of magnesium, AST and CPK enzymes are released into general circulation in large quantities and remain high for several days due to their normal physiological characteristics (Kumar et al., 1993; Smith, 1996). CPK is the most specific and sensitive indicator of muscle damage, so its increaced activity in serum is of clinical significance in diagnosis muscular degeneration and necrosis (Kaneko, 1989). The increaced level of serum alkaline phosphatase was supported by Sonnenwirth and Jarett, (1980) who mentioned that magnesium is an activator of a number of intracellular enzymes including ALP.

The result of thyroid and parathyroid hormones analysis is tabulated in Table (4), showing significant decrease in PTH level in hypomagnesemic calves than the control ones, while, the thyroid hormones, thyroxine (3, 5, 3, 5 tetra iodo-L-thyronine) or $\mathrm{T}_{4}$ and $(3,5,3$ triiodo-L-thyronine) or T3 are within the normal range. Magnesium metabolism is related closely to calcium metabolism and affected by it 
(Randal et al., 2002). PTH which decrease the urinary magnesium excretion, also strictly regulates calcium metabolism through a biphasic effect on bone mineral mobilization. The initial effect is to stimulate the osteocyte - osteoblast pump which moves calcium from the bons fluid compartment into the extracellular fluid compartment. PTH also, stimulates osteoclastic resorption of bone, leading to release much greater quantities of calcium from bone (Griffin and Ojeda, 2000). In hypomagnesmia, there is a decreased in formation and activity of PTH, where, hypomagnesmia cause target organ resistance to the physiologic effects of PTH which ultimately results in hypocalcemia and clinical disease. So, hypocalcemia is often accompaines hypomagnesemia (Dua and Care 1995). From other side, hypomagnesemia may result in suboptimal conditions for enzyme reactions that require magnesium as a cofactor. Protien synthesis necessary for production of receptors for PTH in target cells may be curtailed during magnesium deficiency. Also, decreased activity of adenylate cyclase which requires magnesium as a cofactor, may disrupt the formation of cyclic AMP, the second messenger for PTH (Fontenot et al., 1989). This a negative effect of hypomagnesemia on calcium homeostasis.

The analysis of mineral contents of the soil, plant and concentrate are tabulated in Table (5), showing a decrease in minerals content especially magnesium level than the normal limites of them. El-Toukhy, (1986) reported that the mean values of calcium, phosphorus and magnesium in the Egyptian clay soil (the Delta) were $161.67 \mathrm{ppm}$, 294.28ppm and 212.33ppm respectively. Also, McDonald et al. (1990) mentioned that the mean values of these elments in Trifolium alexandrinum were $1934.00 \mathrm{ppm}, 1811.00 \mathrm{ppm}$ and $2100.00 \mathrm{ppm}$ respectively, depending upon the stage of growth, cultivation conditions and fertilizer application. The decrease in plant minerals may reflect the same decrease of these minerals in the examined soil, where the soil is the primary source of elements on which soil-plant - animal relationships are built. Also, the associations between soil and herbage composition and marginal or functional deficiency in the animal is complex (Underwood and Suttle 1999). So, the decreased magnesium level in the soil and respectively in the plant in this study, may be the primary cause of magnesium deficiency in examined calves. Similar results reported by Dryden (2008).

The results revealed a prolonged magnesium deficiensy, in examined calves where most of them show moderate clinical signs. Similar results obtianed by Odette (2005) who mentioned that mild low 
serum magnesium level may not predict clinical signs, since the neurological manifestations are reflective of cerebrospinal fluid magnesium concentrations which is maintained over a wide range of serum magnesium levels.

\section{Conclusion:}

Hypomagnesaemia is a metabolic disease characterized by low magnesium concentrations in blood. Prevention of it should be aimed at two major goals: continuous provision of adequate levels of magnesium in the diet and maximizing absorption of this essential mineral. Further research concerning the soil, plant and animal, also factors affecting availability of dietary magnesium for transport into the body, seems of paramount importance for control this disease.

\section{REFERENCES}

AOAC (1980): Official methods of analysis. $12^{\text {th }}$ ed. Association of Official Analytical Chemists. Washington, D.C., USA.

Bohuon, C. (1962): Colorimetric determination of magnesium. Anal. Chem. Acta., 7: 811-817.

Dryden, G.M. (2008): Animal Nutrition Science. Cambridge University Press, Cambridge, U.K.

Dua, K. and Care, A.D. (1995): Impaired absorption of magnesium in the aetiology of grass tetany. British Vet. J. 151: 413-426.

El-Toukhy, M.M. (1986): Studies on the status of some nutrient elements in Egyptian soils. Ph.D. Thesis, Fac. Agric., Cairo University.

Fontenot, J.P.; Allen, V.G.; Bunce, G.E. and Goff, J.P. (1989): Factors influencing magnesium absorption and metabolism in ruminants. J. Anim. Sci., 67: 3445-3455.

Gindler, M. (1972): Colorimetric determination of serum calcium. Am. J. Clin. Path. 58: 376-382.

Goldenberg, H. (1966): Colorimetric determination of serum phosphorus. Clin. Chem., 12: 871.

Griffin, J.E. and Ojeda, S.R. (2000): Text book of endocrine phsiology. Fourth edition, Oxford University Press.

Grunes, D.L. (2004): Grass tetany of cattle and sheep. Page 113 in Antiquality components of forages. A.G. Matches, Ed. Crop Sci. Soc. Am., Inc. Madison, WI. 
Herdt, T.H.; Rumbeiha, W. and Emmett Braselton, W. (2000): The use of blood analysis to evaluate mineral status in livestock. Vet. Clin. North. Am. Food. Anim. Pract., 16: 423-444.

Jain, W. (1986): Schalms Veterinary Hematology. $4^{\text {th }}$ ed. Lee and Fibiger, Philadelphia U.S.A.

Jayanthi, M.; Sundar, S.; Karunanidhi S. and Choudhuri, C. (1997): Serum biochemical findings in experimental hypomagnesaemia in buffaloe calves. Indian Vet. J. 74: 752-754.

Kaneko, J.J. (1989): Clinical Biochemistry of Domestic Animals. $4^{\text {th }}$ ed. Academic Press. California. U.S.A.

Kirtidua, J.A. and Nauriyal, D.C. (1988): Clinico-biochemical aspects of experimentally induced hypomagnesaemia in buffaloe calves. Indian J. of Anim. Sci., 85 (1): 38-44.

Kumar, P.; Kumar, M. and Josh, P.H. (1993): Serum enzymes profile in experimental hypomagnesemia in yearling buffaloes. Indian Journal of Animal Sciences. 63 (11): 1152-1155.

Martens, H. and Schweigel, M. (2000): Pathophysiology of grass tetany and other hypomagnesemia implications for clinical management. Vet. Clin. North. Am. Food. Anim. Pract., 16: 339-368.

Mayer, G.P.; Hurst, J.G.; Barto, J.A. Keaton and Moor, M.P. (1979): Effect of epinephrine on thyroid and parathyroid hormones secretion in calves. Endocrinology, 104: 1181-1187.

McDoland, P.; Edwards, R.A. and Greenhalgh, J.F.D. (1990): Animal nutrition, Fourth Edition, ELBS, Longman, UK.

Odette, $O$. (2005): Grass tetany in a herd of beef cows. Can. Vet. J. 46: 732-734.

Radostits, O.M.; Blood, D.C. and Gay, C.C. (2000): Veterinary Medicine: a text book of diseases of cattle, sheep, pigs, goats, and Horses. $8^{\text {th }}$ ed. London: Bailliere Tindall: 1442-1450.

Randal, D.; Burggern, W. and French, K. (2002): Animal physiology, mechanisms and adaptations. $5^{\text {th }}$ ed., W.H Freeman and Company, New York.

REC. GSCC (1977): Colorimetric determination of creatine phosphokinase activity. J. Clin. Biochem., 15: 255.

Sarode, D.B.; Nisal, M.B. and Sapre, V.A. (1992): Alteration in composition of cerebrospinal fluid and blood of experimentally 
induced hypomagnesemia in crossbred calves. Indian Vet. J., 69: 1001-1004.

Smith, B.P. (1996): Large Animal Internal Medicine, $2^{\text {nd }}$ ed. Missouri Mosby; 1474-1479.

Snedecor, G.W. and Cochran, W.G. (1994): Statistical Methods. $8^{\text {th }}$ ed., Iowa State Univ. Press. USA.

Sonnenwirth, A. and Jarett, L. (1980): Grawohl's clinical laboratory methods and diagnosis. $8^{\text {th }}$ ed., Mosby Company.

Thefeld, W.; Purdy, C.W. and Hallford, D.M. (1974): Studies on hypomagnesaemia in ruminants. Dt. Med. Wschr. 99: 343.

Underwood, E.J. and Suttle, N.F. (1999): The mineral nutrition of livestock. $3^{\text {rd }}$ Edition, CAB International Oxon, U.K.

Urdaz, J.H.; Santos, J.E.; Jardon, P. and Overton, M.W. (2003): Importance of appropriate amounts of magnesium in rations for dairy cows. J. Am. Vet. Med. Assoc., 222: 1518-1523.

Vrzgula, L. (1990): Metabolic disorders and their prevention in farm animals. Vol. 24, Elsevier Science Publishing Company, New York.

Young, D.S.; Gagnon, J.; Hoffman, R. and Simpson, J. (1975): Colorimetric determination of alkaline phosphatase. Clin. Chem. 21: 432. 